\title{
Targeting insulin-like growth factor axis in hepatocellular carcinoma
}

\author{
Jennifer $\mathrm{Wu}^{1 *}$ and Andrew $\mathrm{X} \mathrm{Zhu}^{2}$
}

\begin{abstract}
The insulin-like growth factor (IGF) axis contains ligands, receptors, substrates, and ligand binding proteins. The essential role of IGF axis in hepatocellular carcinoma (HCC) has been illustrated in HCC cell lines and in animal xenograft models. Preclinical evidence provides ample indication that all four components of IGF axis are crucial in the carcinogenic and metastatic potential of HCC. Several strategies targeting this system including monoclonal antibodies against the IGF 1 receptor (IGF-1R) and small molecule inhibitors of the tyrosine kinase function of IGF-1R are under active investigation. This review describes the most up-to-date understanding of this complex axis in HCC, and provides relevant information on clinical trials targeting the IGF axis in HCC with a focus on anti-IGF-1R approach. IGF axis is increasingly recognized as one of the most relevant pathways in HCC and agents targeting this axis can potentially play an important role in the treatment of HCC.
\end{abstract}

\section{Introduction}

Hepatocellular carcinoma (HCC) is the $5^{\text {th }}$ most common neoplasm worldwide with more than 600,000 cases per year and the $3^{\text {rd }}$ leading cause of cancer-related death $[1,2]$. For the past 3 decades, the incidence of $\mathrm{HCC}$ in the US has tripled, yet the 1 year survival rate of HCC remains less than 50\% [3]. Currently sorafenib is the only medication that shows overall survival advantage compared to placebo in patients with advanced HCC $[4,5]$. However, the benefits with sorafenib are moderate and its toxicities can be challenging to manage. For patients who fail or cannot tolerate sorafenib, there are currently no standard treatments. Therefore, there is an urgent need to search for novel effective therapies in advanced HCC. Recently, the insulin-like growth factor (IGF) axis has emerged as an important pathway in the development and progression of HCC and as a potential therapeutic target.

Here we review the complexity of IGF axis, the supporting preclinical and clinical data highlighting the significance of this pathway in $\mathrm{HCC}$, and the early clinical trials of targeting this axis in advanced HCC.

\footnotetext{
* Correspondence: jennifer.wu@nyumc.org

'Division of Hematology and Medical Oncology, NYU Cancer Institute, NYU School of Medicine, New York, NY, 10016, USA

Full list of author information is available at the end of the article
}

\section{Components of IGF Axis}

The insulin-like growth factor (IGF) pathway has highly conserved function in mammals and plays a critical role in energy metabolism and cell renewal in response to nutrients [6-11]. IGF pathway is not only involved in cell growth in tissue culture [12,13], but it also promotes cell proliferation, migration and transformation into malignant clone [12,14]. The IGF-1 pathway revolves around 4 essential components.

\section{(1) Ligands}

The first component contains the IGF ligands, which include both insulin-like growth factor 1 (IGF-1) and IGF-2. Their names are based on the observation that both IGF-1 and IGF-2 are peptides, similar to insulin, and they share $40 \%$ homology with proinsulin $[15,16]$. They are, however, slightly different from insulin structurally by containing an additional domain, which could account for their dramatically different role in neoplasms in comparison with insulin [16].

\section{(2) Receptors}

The IGF ligands bind to the second component of the IGF axis, the receptors which include IGF-1 receptor (IGF-1R), IGF-2 receptor (IGF-2R), insulin receptor and hybrid receptors consisting of IGF-1R and insulin receptor hemireceptors (IGF-1R/insulin receptor) (Figure 1). IGF-1 and IGF-2 both bind to IGF-1R with high affinities, 


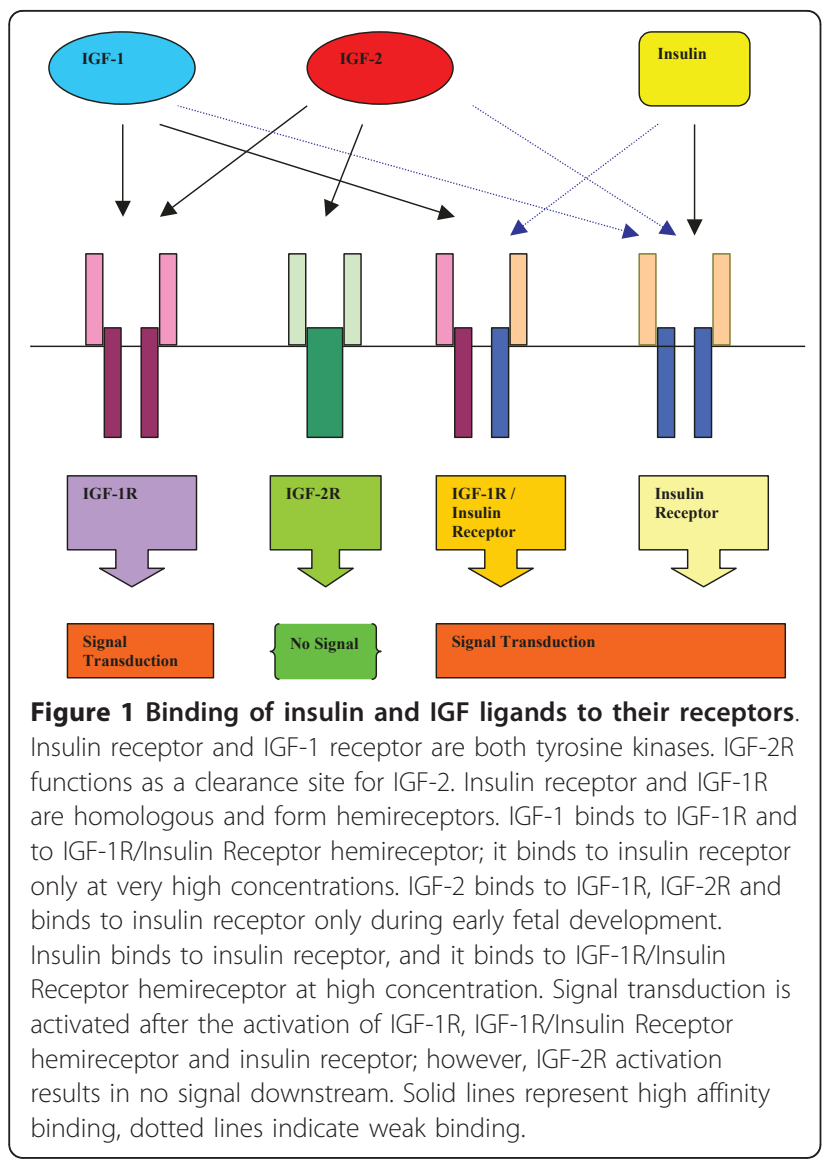

and IGF-2 is the only ligand for IGF-2R $[6,12,15]$. IGF-1 only binds to insulin receptor at extremely high doses, as IGF-1 has 100 fold higher affinity for IGF-1R compared to insulin receptor [16]. IGF-2 usually binds to insulin receptor during fetal development, as later in development when IGF-1R is expressed, IGF-2 binds to IGF-1R more tightly $[16,17]$. Each IGF-1R/insulin receptor hemireceptor only contains one $\alpha$ and one $\beta$ subunit; IGF- 1 is the preferred ligand for IGF-1R/insulin receptor hybrid receptors compared to insulin, as IGF-1 can tightly bind in the presence of only one $\alpha$ subunit of the hemireceptor, while insulin requires two $\beta$ subunits of the hemireceptor to provide optimal binding [16].

\section{(3) Substrates}

The third component of the IGF axis refers to the insulin receptor substrate (IRS) and Shc proteins, which are the major signals downstream of IGF-1R activation [16]. There are 4 types of IRS and the important ones include IRS- 1 and IRS-2.

\section{(4) Ligand Binding Proteins}

The last key component of the IGF axis consists of IGF binding proteins (IGFBPs). There are 6 members of
IGFBPs with high affinities for IGF-1 and IGF-2. For instance, IGFBPs 1-4 bind both IGF-1 and IGF-2 with similar affinities, yet IGFBP- 5 and 6 strongly prefer IGF2 as their ligand.

\section{Physiologic Functions of IGF Ligands and Receptors}

(1) IGF Ligands

(A) IGF-1

The majority of IGF-1 is synthesized in the liver under the influence of growth hormone, which is a major promoter of postnatal growth [18]. However, deletion of liver specific IGF-1 gene in mice showed no difference in growth compared to wild type animals, even though serum IGF-1 level was reduced by $75 \%$ [18-20]. Such observations came with no surprise when later on IGF-1 was found to be produced in other organs such as the kidneys, muscle and bone [16]. IGF-1 can act as an autocrine, paracrine or endocrine growth factor, therefore even minimal amount of IGF-1 could still exert its function on postnatal growth [18-20]. Nutrition depletion reduced IGF-1 levels and risk of cancer [12,21], whereas infusion of IGF-1 abolished the protection against carcinogenesis provided by dietary restriction [22]. Epidemiology studies also indicate that IGF-1 is involved in the risk of cancer development. Several studies suggest that height and weight at birth are proportional to the level of IGF-1 in the umbilical cord, and that infants with higher percentile of height and weight at birth tend to develop more common cancers such as breast, prostate and colorectal later in life [22-28].

(B) IGF-2

IGF-2 shares $60 \%$ homology with IGF-1. Similar to IGF1 , it is also mostly produced in the liver $[6,16]$ and acts in an autocrine, paracrine and endocrine fashion. It is abundant in fetal development, yet its quantity sharply diminishes after birth [16]. IGF-2 knockout mice develop normally except all of them have stunted growth after birth [16], indicating that IGF-2 is critical in growth.

\section{(2) IGF Receptors}

(A) IGF-1 Receptor

The effects of IGF-1R on apoptosis and cell mobility Both IGF-1 and IGF-2 bind to IGF-1 receptor 1(IGF$1 R$ ), a tyrosine kinase that is structurally similar to insulin receptor (IR) (Figure 1). After IGF ligand binding, the $\beta$ subunit of IGF-1R undergoes conformational change which causes autophosphorylation of its own tyrosine kinase domain, which leads to the full activation of IGF-1R. IGF-1R induces anti-apoptosis and increases tumor cell mobility. The anti-apoptotic property of IGF-1R was shown in its response to p53, the tumor suppressor gene that promotes apoptosis. Wild 
type p53 expression inhibited the gene expression of IGF-1R, while mutant p53 increased the gene expression of IGF-1R $[16,29]$. Oncogenes such as Src kinase and Akt kinase both stimulated the gene expression of IGF$1 \mathrm{R}$, providing more evidence that IGF-1R is vital in carcinogenesis [16,29-31]. In addition, IGF-1R also stimulates cell mobility, as demonstrated by its activity in melanoma cell lines [32].

IGF-1R and malignant transformation Another important role of IGF-1R in carcinogenesis is its ability to transform and maintain the transformed phenotype [33]. Mouse embryo fibroblasts possess an extremely strong tendency to spontaneously transform in culture without any additional factors [33], which was no surprise given IGF-1R overexpressed in mouse embryo fibroblasts led to transformation [33-36]. However, when IGF-1R gene in mouse embryo fibroblasts was disrupted, these fibroblasts failed to transform, even in the presence of the most potent oncogenes such as SV40 T antigen, Ha-ras oncogene and activated c-Src [33,37-41]. An even more noteworthy observation was that when IGF-1R was reintroduced, these mouse embryo fibroblasts again restored their ability to rapidly transform.

Toxicities of IGF-1R inhibition IGF-1R is required for anchorage independent growth, and inhibition of IGF-1R causes apoptosis without toxicities in vivo. Human prostate cancer cells usually form anchorage independent growth, however; when IGF-1R was abolished, these cells failed to grow in culture, and the same model showed no tumor formation in mice [33,42-45]. These observations indicate that IGF-1R is an essential requirement for anchorage independent growth, a pattern common in cancer cell proliferation. In animal models with transformed tumors where IGF-1R was overexpressed, strategies that caused IGF-1R downregulation such as antisense against IGF-1R produced profound tumor apoptosis and massive reductions of metastases [46,47]. Interestingly, IGF-1R is not required for normal cell growth, as its absence provided no growth inhibition on monolayer cell culture [45], eluting to the possibility that anti-IGF-1R strategies could produce minimal side effects on normal tissues.

\section{(B) IGF-2 Receptor}

There are no known downstream signals related to IGF$2 \mathrm{R}$ activation and it appears that IGF-2R mainly serves as a clearance site for its only ligand, IGF-2 [6]. Most of the effects of IGF ligands are mediated through IGF-1R, a transmembrane tyrosine kinase $[6,12,16]$.

\section{(3) IGF-1R Substrates}

Among the substrates of IGF-1R, IRS plays a prominent role in exerting the activity of IGF-1R by activating downstream signals [16]. After IGF-1R activation, additional tyrosine residues are then phosphorylated, which act as docking stations for substrates such as the insulin receptor substrate (IRS) and Shc adaptor proteins (Figure 2). IRS and Shc adaptor proteins then recruit additional factors to yield activations of two major cascades, the phosphatidyl inositol 3-kinase (PI3K) and the mitogen-activated protein kinase (MAPK), both result in cell differentiation, proliferation and anti-apoptosis [16,22]. There are currently 4 types of IRS proteins [48], the effects of IRS- 1 and 2 are opposite to that of IRS-3 and 4 [16]. IRS-1 is the most well understood IRS, and it is essential to the activation of IGF$1 \mathrm{R}$. When IRS-1 was abundant, it promoted cell size growth, activated $\mathrm{p} 70{ }^{\mathrm{S} 6 \mathrm{~K}}$, a kinase that promotes cell proliferation and leads to transformation [49]. Meanwhile, IRS-1 turned off IGF-1R's stimulation for differentiation through its phosphotyrosine binding (PTB) domain, therefore inhibited differentiation and stimulated transformation [50]. When IRS-1 was inhibited or malfunctions, such as the case when there was a mutation of its PTB domain, transformation no longer continued and these cells tend to undergo differentiation. The inhibitor of $\mathrm{p} 70^{\mathrm{S} 6 \mathrm{~K}}$ such as rapamycin, which is an inhibitor in the mammalian target of rapamycin (mTOR) pathway, also produced similar effects as the mutated PTB domain, thus cells exposed to rapamycin tend to grow slowly with good differentiation [51].

\section{(4) IGF Binding Proteins}

(A) IGFBP-3 One of the key regulators of IGF expression is the family of IGF Binding Proteins (IGFBPs) [6].

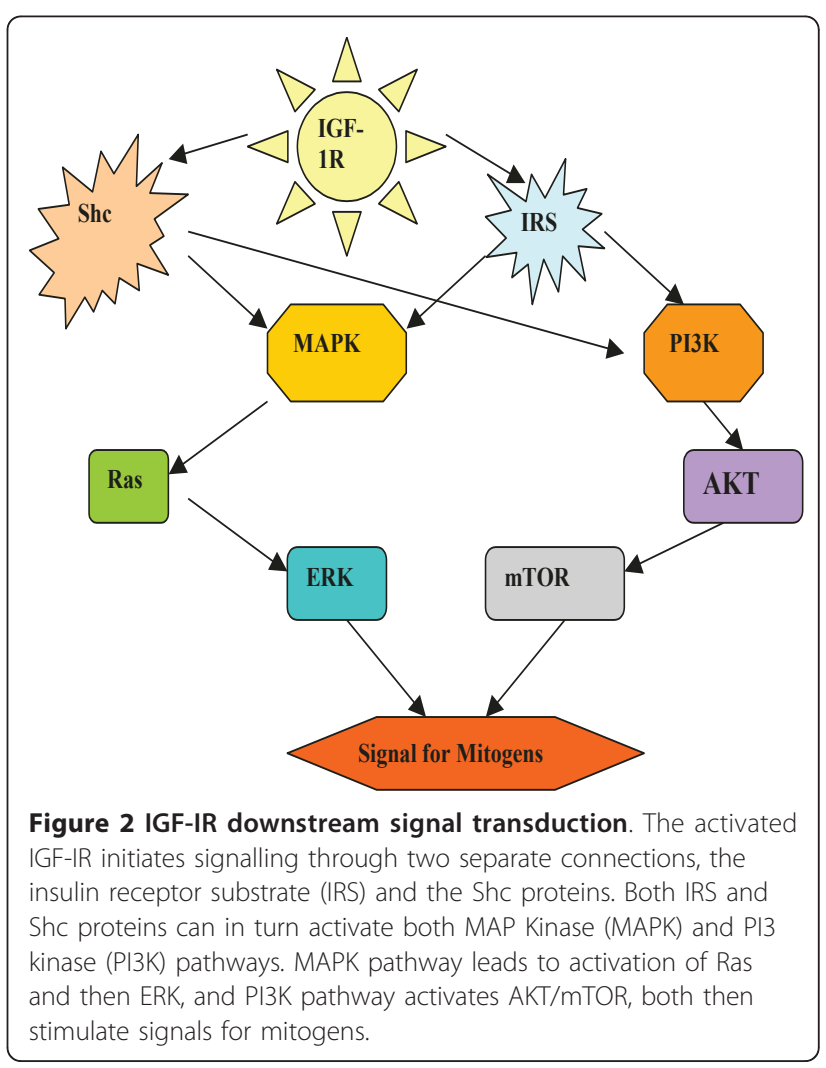


The predominant form of IGFBPs is IGFBP-3, which comprises of $90 \%$ of all IGFBPs in serum $[15,16]$, and it binds to the majority of circulating IGF-1 and IGF-2. IGFBPs that include IGFBPs 1, 3, 4 and 6 usually limit IGF access to IGF-1 receptor, therefore decrease the availability of IGFs and diminish their effects on cancer progression [6].

(B) Other IGFBPs Other IGFBPs such as IGFBP-2 and 5 seem to increase the bioavailability of IGF ligands, therefore play an opposite role of IGFBP-3 [6]. Both in vitro and in vivo evidence support the observation that antisense strategy targeting IGFBP-2 or 5 decreases neoplastic growth $[6,52]$.

\section{Evidence of IGF Axis Involvement in Hepatocarcinogenesis (1) Role of IGF Ligands}

(A) IGF-1 In human HCC tissues, IGF-1 mRNAs were expressed at lower levels than the surrounding normal liver tissues $[18,53]$. This could be related to the observation that growth hormone receptor level was low in HCC tissues $[18,53]$, and growth hormone stimulation thus was low, and the downstream signals such as IGF-1 level would be accordingly low.

\section{(B) IGF-2}

IGF-2 overexpression and its effects on apoptosis and angiogenesis in HCC IGF-2 has been reported to be overexpressed in animal models of hepatocarcinogenesis and in human HCC [50,54-60]. IGF-2 has been linked to carcinogenesis by providing a stimulatory effect on cell proliferation and angiogenesis, both critical in HCC development. In a study using 2 human HCC cell lines, high levels of IGF-2 were demonstrated, and anti-sense oligonucleotides used to target IGF-2 mRNA showed reduction of IGF- 2 mRNA and protein levels, which corresponded to a remarkable decrease in cell proliferation $[18,61]$. In a study of molecular profiling of human HCC samples, overexpression of IGF-2 was related to a cluster of gene signature that downregulates apoptosis [62], indicating a potent anti-apoptotic effect of IGF-2. The relationship between IGF-2 and angiogenesis was demonstrated in human $\mathrm{HCC}$ cell cultures. Under hypoxia environment, IGF-2 mRNA levels in human HCC tissue increased, and IGF-2 overexpression directly increased vascular endothelial growth factor (VEGF) mRNA and protein levels [63]. It suggested a pro-angiogenic effect of IGF-2, an important pathway in HCC development and metastasis.

Animal models of IGF-2 and preneoplastic lesions for HCC In rodents, diethylnitrosamine (DEN) induced 100\% development of glycogen rich hepatic lesions, which are precursors to $\mathrm{HCC}$, and up to $98 \%$ of such lesions expressed IGF-2 mRNA [54,64]. These results highlight a vital role of IGF-2 early in hepatocarcinogenesis. The expression of IGF-2 has been shown to be a common pathway leading to hepatocarcinogenesis regardless of the species or the process of HCC development [65]. In transgenic mice where IGF-2 levels were persistently 20 times higher than normal control mice, a diverse spectrum of tumors were seen at a much higher frequency than the controls, and HCC was the most common malignancy by 18 months of age [66].

Re-emergence of fetal IGF-2 expression in human HCC The expression of IGF-2 is very unique in fetal development, as it is maternally imprinted; therefore it is monoallelic $[6,18]$. In adults, IGF-2 becomes biallelic [18]. In fact, IGF-2 overexpression in HCC showed re-emergence of fetal IGF-2 by the identification of fetal promoter activation [67]. In all 15 samples of human HCC tested in a study, the overexpression of maternally imprinted fetal IGF-2 was demonstrated [51]. In a study from Hong Kong, $30 \mathrm{HCC}$ samples from patients examined using northern blot analysis showed more than $93 \%$ of the adult promoter IGF-2 transcripts were repressed, while $93 \%$ of the adult type IGF-2 transcripts were detected in nontumourous tissues $[68,69]$.

The Interaction of IGF-2 with HCC risk factors The importance of IGF-2 in HCC development is further demonstrated in its relationship with risk factors of HCC such as hepatitis B and C [70]. In patients with chronic hepatitis $\mathrm{C}$ and cirrhosis, the overexpression of IGF-2 was clearly related to hepatitis $C$ viral replication [71]. In patients with chronic hepatitis B, HBV X protein stimulated IGF-2 expression by binding to the fetal promoter of IGF-2, therefore directly stimulating fetal transcript expression of IGF-2 in HCC [72]. Furthermore, aflatoxin has been shown to be synergistic with hepatitis B in the carcinogenesis of HCC, and p53 gene mutation induced by aflatoxin increased the expression of IGF-2 in HCC patients with hepatitis B infection [73]. (2) Role of IGF Receptors

IGF-1R overexpression in vitro in HCC In a study where $10 \mathrm{HCC}$ cell lines (including PLC HCC cell line) were tested, all of them showed elevated IGF-1R mRNA [50]. Furthermore, the addition of both IGF-1 and IGF2 to the PLC HCC cell line induced increased cell proliferation in a dose dependent manner, showing that the major tumor promoting effects of IGF ligands on HCC are exerted through IGF-1R [46].

IGF-1R overexpression in animal models of hepatocarcinogenesis In a model utilizing pancreatic islet transplantation into the livers of diabetic rats, a well established series of events led to development of HCC from preneoplastic foci [74]. When HCC developed from preneoplastic foci in this animal model, the expression of IGF-1R significantly increased, which could explain the phenomenon that the increase in mitotic activity was more than the increase in the rate of apoptosis $[18,75]$. 
IGF-1R is therefore crucial in both the development of and the growth of HCC, making IGF-1R an ideal target in the treatment of HCC.

The Inhibitory effects of IGF-2R on IGF-1R IGF-2R is closely associated with transforming growth factor $\beta$ (TGF- $\beta$ ), a very potent growth inhibitor [76]. For instance, in human HCC tissues, the levels of both TGF$\beta$ and IGF-2R protein were reduced compared to those in adjacent normal liver tissues [66]. The expression of IGF-2R was significantly lower in several HCC cell lines in vitro, in HCC animal models and in human HCC tissues $[77,78]$. The role of IGF-2R in IGF axis appears to serve as a site for IGF-2 clearance, therefore reduces the availability of a potent ligand for IGF-1R, the major gateway for carcinogenesis, tumor growth and proliferation. IGF-2R therefore provides an indirect inhibitory effect on IGF-1R.

(3) Role of IGF Substrates

(A) IRS-1 The overexpression of IRS-1 has been described in human HCC cell lines and tissues [79]. IRS-1 leads to activation of downstream mitogens such as PI3K and MAPK. In human HCC cell lines, IRS-1 developed acquired resistance to apoptosis, indicating a potent role of IRS-1 in the promotion of continued cell growth in HCC [79].

(B) IRS-2 IRS-2 is a major downstream signal of insulin pathway in the liver, and its function in hepatocarcinogenesis is demonstrated in animal models. When SV40 large $\mathrm{T}$ antigen or DEN was applied in murine models, IRS-2 overexpression was detected in both preneoplastic foci and HCC lesions, with higher levels in HCC nodules [47]. A similar observation was reproduced in human HCC cell lines and tissue specimens, suppression of IRS-2 levels led to increased apoptosis. Together with IRS-1, IRS-2 also contributes to hepatocarcinogenesis, as demonstrated by its early emergence in preneoplastic lesions, and its antiapoptotic property. IRS- 1 and 2 therefore create an optimal environment for HCC growth.

\section{(4) Roles of IGFBPs}

(A) IGFBP-3 In a study comparing IGFBP-3 levels in human normal liver, cirrhotic liver and HCC, the expression of IGFBP-3 mRNA levels was significantly reduced in HCC [80]. In a human HCC cell line, addition of exogenous IGFs stimulated mitosis, but this mitogenic effect was greatly reduced by IGFBP-3 [46]. Furthermore, addition of recombinant human IGFBP-3 induced growth inhibition of the human HCC cell lines HepG2 and PLC [81]. The role of IGFBP-3 on tumor growth inhibition can be further explained by IGFBP-3's induction by p53, a tumor suppressor gene essential in apoptosis and cell cycle arrest [15].

(B) IGFBP-7 In a study examining radiation induced HCC mouse model, northern analysis showed decreased expressions of IGFBP-7 (a low affinity IGFBP) in HCC compared to normal liver tissues, which was inversely related to anchorage-independent growth in HCC cell lines [82]. A similar trend of reduced IGFBP-7 level was seen in human HCC tissues. When IGFBP-7 cDNA was injected to radiation induced $\mathrm{HCC}$ mouse model, the volume of HCC was greatly reduced. IGFBP-7, although has relatively low affinity toward IGF-1 and IGF-2, exerts a similar anti-tumor effect as its high affinity IGFBP counterpart IGFBP-3.

(C) IGFBP protease inhibitors Metalloproteinase belongs to IGFBP proteases that degrade IGFBP-3. In a transgenic murine HCC model overexpressing the inhibitor of metalloproteinase (TIMP1), IGFBP-3 degradation was reduced, and serum level of IGFBP-3 was subsequently increased, which decreased the bioavailable IGF-2 ligand and its downstream signalling. This resulted in reduced liver hyperplasia, despite the activation of IGF-2 by a strong oncogene such as SV40 T antigen [83]. It provided evidence that IGFBP proteases and IGFBPs are equally important in the regulation of IGF ligand bioavailability and their downstream effects on IGF axis activation.

\section{Targeting IGF System and Early Clinical Trials}

There are several strategies in the therapeutic considerations involving IGF axis in the treatment of HCC and other tumors. The first method targets the ligand to reduce its activity, the second inhibits the function of the receptor, and the third modulates the downstream signals of IGF-1R pathways (Table 1).

\section{(1) Anti-Ligand Approach}

One of the first drugs to be tested was somatostatin. However, as it only lowered serum IGF-1 level to a modest degree without achieving desired reduction, it showed no anti-neoplastic activity [84]. Metformin lowered insulin levels in patients with hyperinsulinemic states such as in obesity, a major risk factor for HCC. The reduction of insulin was significant, yet its effect on IGF-1 and IGF-2 was minimal, making metformin a weak candidate in the treatment of HCC [85]. Ongoing studies utilizing growth hormone antagonists or IGF ligand specific antibodies have demonstrated some activity in prostate and breast cancer cell lines, suggesting their potential in the treatment of HCC $[86,87]$. MEDI-573 is a first in human neutralizing antibody against both IGF-1 and IGF-2, has shown promising activity in vivo based on its inhibition of downstream IGF signalling [88], and is now being tested in phase I solid tumors.

\section{(2) Anti-Receptor Approach}

(A) Monoclonal antibodies of IGF-1R

Single agent activity of monoclonal antibodies of IGF$1 R$ in vitro, in vivo and in phase I solid tumors The majority of anti-IGF strategies focused on IGF-1R, the 
Table 1 Agents in clinical development that target the insulin-like growth factor pathway

\begin{tabular}{|c|c|c|c|c|c|}
\hline Company & Compound & Mechanism of Action & $\begin{array}{l}\text { Phase of Clinical } \\
\text { Development }\end{array}$ & Dosing & Types of Cancers Tested \\
\hline MedImmune & MDI-573 [89] & $\begin{array}{l}\text { Fully human monoclonal } \\
\text { antibody of IGF-1 and IGF-2 }\end{array}$ & I & IV every 3 weeks & Solid tumors \\
\hline Merck & MK-0646 [90] & $\begin{array}{l}\text { Monoclonal antibody of IGF- } \\
1 \mathrm{R}\end{array}$ & $\|$ & $\begin{array}{l}\text { IV weekly, } 3 \text { weeks } \\
\text { on, } 1 \text { week off }\end{array}$ & $\begin{array}{l}\text { Non-small cell lung cancer, small cell lung } \\
\text { cancer, prostate, breast, pancreas }\end{array}$ \\
\hline Imclone & $\begin{array}{l}\text { IMC-A12 } \\
{[91,99]}\end{array}$ & $\begin{array}{l}\text { Fully human Monoclonal } \\
\text { antibody of IGF-1R }\end{array}$ & $\|$ & $\begin{array}{l}\text { IV every } 1 \text { or } 2 \\
\text { weeks }\end{array}$ & $\begin{array}{l}\text { HCC, Colorectal, pancreas, mesothelioma, } \\
\text { thymoma, prostate, head and neck }\end{array}$ \\
\hline Biogen-Idec & BIIB 022 [92] & $\begin{array}{l}\text { Monoclonal antibody of IGF- } \\
1 \mathrm{R}\end{array}$ & $|/| \mid$ & IV every 2 weeks & HCC, non-small cell lung cancer \\
\hline $\begin{array}{l}\text { Sanofi- } \\
\text { Aventis }\end{array}$ & AVE 1642 [98] & $\begin{array}{l}\text { Humanized antibody of IGF- } \\
1 \mathrm{R}\end{array}$ & I & IV every 3 weeks & HCC, multiple myeloma \\
\hline Roche & R1507 [118] & $\begin{array}{l}\text { Fully human IgG1 } \\
\text { recombinant antibody of IGF- } \\
1 \mathrm{R}\end{array}$ & । & Every 1 or 3 weeks & Solid tumors and Lymphoma \\
\hline Amgen & AMG 479 [119] & $\begin{array}{l}\text { Fully human Monoclonal } \\
\text { antibody of IGF-1R }\end{array}$ & $\|/\| \|$ & IV every 2 weeks & $\begin{array}{l}\text { Pancreas, colorectal, Ewing's sarcoma, } \\
\text { ovarian }\end{array}$ \\
\hline Pfizer & CP-751871 [93] & $\begin{array}{l}\text { Fully human Monoclonal } \\
\text { antibody of IGF-1R }\end{array}$ & $\|/\| \|$ & IV every 3 weeks & Non-small cell lung cancer \\
\hline$\overline{\mathrm{OSI}}$ & OSI-906 [100] & $\begin{array}{l}\text { Small molecule inhibitor of } \\
\text { IGF-1R }\end{array}$ & $\|/\| \|$ & Oral twice a day & Adenocortical carcinoma, Ovarian \\
\hline Novartis & $\begin{array}{l}\text { AEW54, } \\
\text { ADW742 } \\
{[120,121]}\end{array}$ & $\begin{array}{l}\text { Small molecule inhibitor of } \\
\text { IGF-1R }\end{array}$ & preclinical & NA & NA \\
\hline BMS & $\begin{array}{l}\text { BMS-554417 } \\
{[102]}\end{array}$ & $\begin{array}{l}\text { Small molecule inhibitor of } \\
\text { IGF-1R }\end{array}$ & preclinical & NA & NA \\
\hline
\end{tabular}

key component of IGF axis that provides mitogenic signal for tumor growth. The most common strategy utilized is the receptor-specific antibodies. For instance, pharmacodynamic studies of MK-0646 (Merck) on neoplastic tissues demonstrated reduction of phosphorylated AKT and phosphorylated S6 kinase, two downstream targets of IGF-1R. MK-0646 also decreased tumor proliferation as shown by reduction in the proliferation marker Ki67 [89,90]. This observation provided a rationale to use this class of antibodies in the treatment of $\mathrm{HCC}$, and it was supported by additional data generated using IMC-A12 (Imclone), a human monoclonal antibody that blocks IGF-1R, both in vitro and in vivo [91]. In hepatoma cell lines, 2 hour incubation with IMC-A12 completely blocked downstream signalling of IGF-1R as shown by the suppression of phosphorylated AKT and phosphorylated S6 kinase [91]. In addition, 10 day treatment with IMC-A12 in HCC xenografts led to $40 \%$ reduction of tumor volume and $40 \%$ prolongation of overall survival without additional toxicity compared to control animals [91]. In a phase I study of refractory solid tumors using IMC-A12 as a single agent, a patient with HCC had stable disease for up to 9 months [92].

Monoclonal antibodies of IGF-1R in combination with chemotherapy in Phase II and III studies One of the most studied IGF-1R antibodies is CP-751871 (Pfizer) and it showed rather promising activity in a phase
II study in patients with advanced non-small cell lung cancer. When it was added to carboplatin and paclitaxel as a first line regimen, the response rate increased from $32 \%$ to $46 \%$. What was even more impressive was in patients with squamous histology, the response rate was as high as $71 \%$ [93]. The most common side effect in this phase II study was hyperglycemia. The subsequent ambitious Phase III study looked at patients with stage IIIB or IV non-small cell lung cancer, and randomized them to receive carboplatin and paclitaxel either with or without CP-751871. This study was halted in late 2009 due to unexpected increase in fatal events in the experimental arm [93], and it could be partially explained by the most common side effect of hyperglycemia. The consequence of IGF-1R inhibition leads to compensatory increase of growth hormone stimulation that promotes liver gluconeogenesis, resulting in hyperglycemia [94]. What we could learn from this surprising result is that there are subsets of patients who could potentially benefit from IGF-1R inhibitors such as CP-751871 [95]. For instance, in the experimental arm, patients with low IGF-1 levels $(<5 \mathrm{pg} / \mathrm{ml})$ before treatment with CP75871 were more likely to suffer fatal events within 60 days of treatment. The same group of patients also had much shorter median overall survival compared to the ones with higher pretreatment IGF-1 levels (7 months vs. 10.4 months). Conversely, for patients with higher 
pretreatment IGF-1 levels, those who received the experimental treatment that included CP-751871 had a trend toward higher median overall survival compared to those who received the standard chemotherapy (10.2 months vs. 7 months). Further analysis from the phase II study also showed that IGF-1R was present in the highest level in patients with squamous histology, which could explain the observed high response rate in squamous cell patients who received CP-75871 [96]. Such observation was consistent with a presentation at ASCO GI in 2011, in which data of 288 patients with HCC were analyzed. In this study, pretreatment lower plasma IGF-1 and higher plasma VEGF levels significantly correlated with advanced clinicopathologic parameters and poor overall survival, with an optimal cut off point of 26 $\mathrm{pg} / \mathrm{mL}$ and $450 \mathrm{pg} / \mathrm{mL}$, respectively. The combination of low IGF-1 and high VEGF predicted median overall survival of 2.7 months compared with 19 months for patients with high IGF-1 and low VEGF ( $\mathrm{p}<0.0001)$ [97]. Such information provided insights into the specific patient subsets in HCC where IGF-1 levels would offer additional prognostic significance. Whether baseline plasma IGF-1 levels could be used to predict response to IGF axis inhibition in HCC remains to be explored.

IGF-1R monoclonal antibodies in HCC IMC-A12 was studied as a single agent in patients with advanced HCC as a front line systemic therapy. This study unfortunately was terminated due to futility. The pre-planned primary endpoint of progression free survival rate at 4 months was only $30 \%$ and median overall survival of 8 months [98]. Up to $46 \%$ of patients developed grade 3-4 hyperglycemia, similar to what was seen in the phase II NSCLC study of CP-751871 [93], thus raising the possibility that hyperglycemia could be the dose limiting toxicity of IGF$1 \mathrm{R}$ monoclonal antibodies. Hyperglycemia and its subsequent increase of growth hormone could also contribute to the disappointing activity of this class of drugs. BIIB022 (Biogen-Idec) is an anti-IGF-1R monoclonal antibody that blocks binding of both IGF-1 and IGF- 2 to IGF-1R [92]. It does not contain Fc effector function, therefore can potentially minimize toxicities in healthy tissues expressing IGF-1R [92]. This agent does not appear to cause hyperglycemia, a common side effect of receptor specific antibodies [92]. Hyperglycemia has been attributed to insulin resistance secondary to high levels of growth hormone, a compensatory reaction to IGF-1R antibodies [94,95]. The class of IGF-1R monoclonal antibodies share similar side effect profiles, including minimal dose limiting toxicities. These favorable safety profiles make them ideal candidates in the combination therapy with current available chemotherapy or biologic therapy [6]. BIIB022 showed inhibition of tumor growth in HCC cell line HepG2, and this inhibitory effect was enhanced by addition of sorafenib [92], the only FDA approved medication for patients with advanced HCC. A planned phase I/II study comparing sorafenib with or without BIIB022 in patients with advanced HCC was terminated due to a business decision of Biogen-Idec. AVE-1642 (Sanofi-Aventis) is another IGF-1R antibody that was initially studied in advanced HCC patients in a phase I study in combination with sorafenib [99], the study was terminated not related to either efficacy or toxicity concerns. Although IMC-A12 lacks single agent activity in $\mathrm{HCC}$, its combination with sorafenib could potentially yield synergy. It is currently undergoing phase I study in combination with sorafenib in patients with HCC, the result of this clinical trial may help understand the clinical benefits of combining IGFR-1R monoclonal antibodies and sorafenib in HCC.

\section{(B) Small molecule inhibitors of IGF-1R}

A major advantage of small molecule inhibitor is its ability to inhibit both IGF-1R and insulin receptor. Such ability was demonstrated in several human tumor cell lines, where phosphorylated IGF-1R and its downstream proteins, including ERK and $\mathrm{p} 70^{\mathrm{s} 6 \mathrm{k}}$ were all effectively inhibited by OSI-906 (OSI) [100]. In addition, it inhibited phosphorylated insulin receptor in both primary human hepatocytes and HCC cell line HepG2. IGF-1R and insulin receptor interaction has been seen in many human tumor cell lines after the appearance of IGF-1R monoclonal antibodies. For instance, when IGF-1R phosphorylation was reduced with the treatment of IGF-1R monoclonal antibody, phosphorylated insulin receptor also increased [100].

Even though IGF-1R plays a dominant role in the activation of IGF axis, insulin receptor becomes very important when IGF-1R is blocked, such as the case with IGF-1R monoclonal antibodies. When IGF-1R is blocked, all the IGF-1 and IGF-2 (ligands for IGF-1R) are available to bind insulin receptor. There are 3 ways how insulin receptor activates the IGF axis. First, when IGF-1 levels increase with IGF-1R inhibition, its binding to insulin receptor also increases, which leads to more insulin receptor activation. Second, IGF-2 usually binds to insulin receptor with very low affinity, however; when IGF-2 fetal transcripts are reactivated, such as in HCC, the affinity of IGF-2 for insulin receptor increases dramatically. Additional insulin receptor is therefore turned on through IGF-2. Third, the overexpression of insulin receptor was demonstrated in numerous human cancers including HCC, and its overexpression was linked to tumor growth and cell survival [101].

\section{BMS-554417}

Several small molecule tyrosine kinase inhibitors of IGF-1R such as BMS-554417 (Bristol-Myers-Squibb) are under development [102-107]. There have been encouraging in vitro and in vivo data in broad range 
of cancers with activated IGF axis. Current phase I data on drug tolerability will provide more information regarding the feasibility of such medications in the potential treatment for advanced HCC.OSI-906 OSI-906 (OSI) is a potent tyrosine kinase inhibitor of both IGF-1R and insulin receptor. The unique advantage of OSI-906 over previous class of anti-IGF drugs is its ability to minimize the activity of IGF-2 where IGF-1R inhibition alone will not be sufficient. In cancers such as adenocortical carcinoma and HCC, where insulin receptor binds to IGF ligands with higher affinity, OSI-996 is able to inhibit both insulin receptor and IGF-1R to achieve maximum inhibition of the IGF axis [108-110]. A phase III study using OSI-906 in patients with adenocortical carcinoma is ongoing. OSI-906 is therefore considered one of the desirable drugs to be tested in patients with HCC.

\section{(3) Approach that targets other pathways}

AMP-activated protein kinase (AMPK) pathway is one of the upstream signalling pathways above mTOR [6]. The AMPK activation effects are quite complex, and although experimental models of AMPK activators demonstrate their anti-proliferation effects, they could also potentiate cell survival after exposure to stress [110-113]. Additional studies on activators of AMPK are required to understand the role of such class of medications prior to its use as anti-neoplastic agents. Another active downstream signal of IGF axis is the mTOR pathway, which is downstream of PI3K/AKT signal. Everolimus (Novartis) is being studied in patients with sorafenib refractory HCC in a phase III trial. A third active pathway involves MAPK, and inhibitors of this pathway are currently in very early phase of investigation [114].

\section{(4) Combination Therapies}

As most of IGF-1R inhibitor molecules have minimal dose limiting toxicities in phase I studies, and IGF-1R activation reduces responsiveness of antineopalstic therapies [6], it is possible to combine IGF-1R inhibitors with certain chemotherapies. For instance, IGF-1R overexpression has been associated with resistance to epidermal growth factor receptor (EGFR) inhibitors and mTOR inhibitors $[115,116]$. The idea of combining IGF-1R inhibitors and agents such as erlotinib or everolimus could be a promising strategy in the management of advanced HCC.

\section{Conclusions}

In recent years, the understanding of IGF pathway in cancer has led to development of IGF inhibitors which show promising anti-cancer signals in early phase I studies. According to the World Health Organization, more than $50 \%$ of cancers come from countries where obesity is a prominent risk factor, and that cancer mortality now is more than that of tuberculosis, malaria and AIDS combined [117]. In the next 3 decades, the incidence of HCC in the US is expected to be among the fastest growing cancers partly due to the increasing incidence of obesity $[6,12]$. IGF axis is an essential pathway in the development of hyperinsulinemia, a condition closely related to obesity, which in turn increases the risk for HCC [6]. Agents that target the IGF axis, an active pathway in carcinogenesis and progression of HCC, provide an alternative strategy in the management of HCC. We are only in the beginning era of realizing the complexities of IGF pathway, additional research in the understanding of both basic science and clinical applications of anti-IGF agents will provide insights into the value of IGF inhibition in the treatment of HCC.

\section{Abbreviations}

HCC: hepatocellular carcinoma; IGF: insulin-like growth factor; IGF-1: insulinlike growth factor 1; IGF-2: insulin-like growth factor 2; IGF-1R: insulin-like growth factor 1 receptor; IGF-2R: insulin-like growth factor 2 receptor; IRS: insulin receptor substrate; IGFBPs: insulin like growth factor binding proteins; PI3K: phosphatidyl inositol 3-kinase; MAPK: mitogen-activated protein kinase; PTB: phosphotyrosine binding; mTOR: mammalian target of rapamycin; VEGF: vascular endothelial growth factor; DEN: diethylnitrosamine; TGF- $\beta$ : tumor growth factor beta; AMPK: AMP-activated protein kinase; EGFR: epidermal growth factor receptor.

\section{Acknowledgements}

We thank Biogen-Idec and OSI for providing essential information on BIIB022 and OSI-906, respectively.

\section{Author details}

${ }^{1}$ Division of Hematology and Medical Oncology, NYU Cancer Institute, NYU School of Medicine, New York, NY, 10016, USA. ²Division of Hematology and Medical Oncology, Massachusetts General Hospital Cancer Center, Harvard Medical School, Boston, MA, 02114, USA.

\section{Authors' contributions}

JW contributed to the collection and interpretation of data, helped drafting the manuscript. AXZ conceived and designed the study, provided critical revisions of its intellectual content, and gave final approval of the version to be published. All authors read and approved the final manuscript

Competing interests

The authors declare that they have no competing interests.

Received: 26 May 2011 Accepted: 5 July 2011 Published: 5 July 2011

\section{References}

1. Jemal A, Siegel R, Ward E, Hao Y, Xu J, Murray T, Thun MJ: Cancer statistics. CA Cancer J Clin 2008, 58:71-96.

2. El-Serag HB, Davila JA, Petersen NJ, McGlynn KA: The continuing increase in the incidence of hepatocellular carcinoma in the United States: an update. Ann Intern Med 2003, 139:817-823.

3. Altekruse SF, McGlynn KA, Reichman ME: Hepatocellular carcinoma incidence, mortality, and survival trends in the United States from 1975 to 2005. J Clin Oncol 2009, 27:1485-1491.

4. Llovet JM, Ricci S, Mazzaferro V, Hilgard P, Gane E, Blanc JF, de Oliverira AC, Santoro A, Raoul JL, Forner A, Schwartz M, Porta C, Zeuzem S, Bolondi L, Greten TF, Galle PR, Seitz JF, Borbath I, Haussinger D, Giannaris T, Shan M, Moscovici M, Voliotis D, Bruix J: Sorafenib in advanced hepatocellular carcinoma. New Eng J Med 2008, 359:378-390. 
5. Cheng AL, Kang YK, Chen Z, Tsao CJ, Qin S, Kim JS, Lou R, Feng J, Ye S, Yang TS, Xu J, Sun Y, Liang H, Liu J, Wang J, Tak WY, Pan H, Burock K, Zou J, Voliotis D, Guan Z: Efficacy and safety of sorafenib in patients in the Asia-Pacific region with advanced hepatocellular carcinoma: a phase III randomised, double-blind, placebo-controlled trial. Lancet Oncol 2009, 10:25-34.

6. Pollak M: Insulin and insulin-like growth factor signalling in neoplasia. Nature Rev Cancer 2008, 8:915-928.

7. Steiner DF, Chan SJ, Welsh JM, Kwok SC: Structure and evolution of the insulin gene. Annu Rev Genet 1985, 19:463-484.

8. De Meyts P: Insulin and its receptor: structure, function and evolution. Bioessays 2004, 26:1351-1362.

9. Dong MQ, Venable JD, Au N, Xu T, Park SK, Cociorva D, Johnson J, Dillin A, Yates JR: Quantitative mass spectrometry identifies insulin signaling targets in C. elegans. Science 2007, 317:660-663.

10. Toyoshima Y, Monson C, Duan C, Wu Y, Gao C, Yakar S, Sadler KC, LeRoith D: The role of insulin receptor signaling in zebrafish embryogenesis. Endocrinology 2008, 149:5996-6005.

11. Shaw RJ, Lamia KA, Vasquez D, Koo SH, Bardeesy N, Depinho RA, Montminy M, Cantley LC: The kinase LKB1 mediates glucose homeostasis in liver and therapeutic effects of metformin. Science 2005, 310:1642-1646.

12. Pollak M, Schernhammer ES, Hankinson SE: Insulin-like growth factors and neoplasia. Nature Rev Cancer 2004, 4:505-518.

13. Jones Jl, Clemmons DR: Insulin-like growth factors and their binding proteins: biological actions. Endocr Rev 1995, 16:3-34.

14. Khandwala HM, McCutcheon IE, Flyvbjerg A, Friend KE: The effects of insulin-like growth factors on tumorigenesis and neoplastic growth. Endocr Rev 2000, 21:215-244.

15. Furstenberger $\mathrm{G}$, Senn $\mathrm{HJ}$ : Insulin-like growth factors and cancer. Lancet Oncol 2002, 3:298-302.

16. LeRoith $D$, Roberts $C T$ Jr: The insulin-like growth factor system and cancer. Cancer Lett 2003, 195:127-137.

17. Rother Kl, Accili D: Role of insulin receptors and IGF receptors in growth and development. Pediatr Nephrol 2000, 14:558-561.

18. Scharf JG, Dombrowski F, Ramadori G: The IGF axis and hepatocarcinogenesis. Mol Pathol 2001, 54:138-144.

19. Sjogren K, Liu JL, Blad K, Skrtic S, Vidal O, Wallenius V, LeRoith D, Törnell J, Isaksson OG, Jansson JO, Ohlsson C: Liver-derived insulin-like growth factor I (IGF-I) is the principal source of IGF-I in blood but is not required for postnatal body growth in mice. Proc Natl Acad Sci USA 1999, 96:7088-7092.

20. Yakar S, Liu JL, Stannard B, Butler A, Accili D, Sauer B, LeRoith D: Norma growth and development in the absence of hepatic insulin-like growth factor I. Proc Natl Acad Sci USA 1999, 96:7324-7329.

21. Khandwala HM, McCutcheon IE, Flyvbjerg A, Friend KE: The effects of insulin-like growth factors on tumorigenesis and neoplastic growth. Endocr Rev 2000, 21:215-244.

22. Vatten $L$, Nilsen ST, Odegard RA, Romundstad PR, Austgulen R: Insulin-like growth factor-I and leptin in umbilical cord plasma and infant birth size at term. Pediatrics 2002, 109:1131-1135.

23. Houghton PJ, Huang S: mTOR as a target for cancer therapy. Curr Top Microbiol Immunol 2004, 279:339-359.

24. Dunn SE, Kari FW, French J, Leininger JR, Travlos G, Wilson R, Barrett JC Dietary restriction reduces IGF-1 levels, which modulates apoptosis, cell proliferation, and tumor progression in p53 deficient mice. Cancer Res 1997, 57:4667-4672.

25. McCormack VA, Silva IdS, De Stavola BL, Mohsen R, Leon DA, Lithell HO: Fetal growth and subsequent risk of breast cancer: results from long term follow up of Swedish cohort. British Med J 2003, 326:248-251.

26. Sandhu MS, Luben R, Day NE, Khaw KT: Self-reported birth weight and subsequent risk of colorectal cancer. Cancer Epidemiol Biomarkers Prev 2002, 11:935-938.

27. Tibblin G, Eriksson M, Cnattingius S, Ekbom A: High birthweight as a predictor of prostate cancer risk. Epidemiology 1995, 6:423-424.

28. Gunnell D, Okasha M, Smith GD, Oliver SE, Sandhu J, Holly JM: Height, leg length, and cancer risk: a systematic review. Epidemiol Rev 2001, 23:313-342.

29. Werner H, Karnieli E, Rauscher FJ, LeRoith D: Wild-type and mutant p53 differentially regulate transcription of the insulin-like growth factor I receptor gene. Proc Natl Acad Sci USA 1996, 93:8318-8323.
30. LeRoith D, Werner H, Beitner-Johnson D, Roberts $C T$ Jr: Molecular and cellular aspects of the insulin-like growth factor I receptor. Endocr Rev 1995, 2:143-163.

31. Tanno S, Mitsuuchi Y, Altomare DA, Xiao DH, Testa JR: AKT activation upregulates insulin-like growth factor I receptor expression and promotes invasiveness of human pancreatic cancer cells. Cancer Res 2001, 61:589-593.

32. Satyamoorthy K, Li G, Vaidya B, Kalabis J, Herlyn M: Insulin-like growth factor-l-induced migration of melanoma cells is mediated by interleukin8 induction. Cell Growth Differ 2002, 13:87-93.

33. Valentinis B, Baserga R: IGF-1 receptor signalling in transformation and differentiation. Mol Pathol 2001, 54:133-137.

34. Kaleko M, Rutter WJ, Miller AD: Overexpression of the human insulin-like growth factor 1 receptor promotes ligand-dependent neoplastic transformation. Mol Cell Biol 1999, 10:464-473.

35. Liu D, Zong CS, Wang LH: Distinctive effects of the carboxyl-terminal sequence of the insulin-like growth factor I receptor on its signalling functions. J Virol 1993, 67:6835-6840.

36. Pietrzkowski Z, Lammers R, Carpenter G, Soderquist AM, Limardo M, Phillips PD, Ullrich A, Baserga R: Constitutive expression of insulin-like growth factor I and insulin-like growth factor 1 receptor abrogates all requirements for exogenous growth factors. Cell Growth Differ 1992, 3:199-205

37. Sell C, Rubini $M$, Rubin R, Liu JP, Efstratiadis A, Baserga R: Simian virus 40 large tumor antigen is unable to transform mouse embryonic fibroblasts lacking type 1 insulin-like growth factor receptor. Proc Natl Acad Sci USA 1993, 90:11217-11221.

38. Liu JP, Baker J, Perkins AS, Robertson EJ, Efstratiadis A: Mice carrying null mutations of the genes encoding insulin-like growth factor I (igf-1) and type 1 IGF receptor (Igflr). Cell 1993, 75:5972

39. Baker J, Liu JP, Robertson EJ, Efstratiadis A: Role of insulin-like growth factors in embryonic and postnatal growth. Cell 1993, 75:73-82.

40. Sell C, Dumenil G, Deveaud C, Miura M, Coppola D, DeAngelis T, Rubin R, Efstratiadis A, Baserga R: Effect of a null mutation of the type 1 IGF receptor gene on growth and transformation of mouse embryo fibroblasts. Mol Cell Biol 1994, 14:3604-3612.

41. Valentinis B, Morrione A, Taylor SJ, Baserga R: Insulin-like growth factor 1 receptor signaling in transformation by src oncogenes. Mol Cell Biol 1997, 17:3744-3754.

42. Baserga R: The contradictions of the IGF-I receptor. Oncogene 2000, 19:5574-5581.

43. Reiss K, D'Ambrosio C, Tu X, Tu C, Baserga R: Inhibition of tumor growth by a dominant negative mutant of the insulin-like growth factor I receptor with the bystander effect. Clin Cancer Res 1988, 4:2647-2655.

44. Baserga R: The price of independence. Exp Cell Res 1997, 236:1-3.

45. Ludwig T, Eggenschwiler J, Fisher P, D'Ercole AJ, Davenport ML, Efstratiadis A: Mouse mutants lacking the type 2 IGF receptor (IGF2R) are rescued from perinatal lethality in lgf2 and Igflr null backgrounds. Dev Biol 1996, 177:517-535.

46. Rodriguez-Tarduchy G, Collins MKL, Garcia I, Lopez-Rivas A: Insulin-like growth factor-I inhibits apoptosis in IL-3-dependent hemopoietic cells. J Immunol 1992, 149:535-540.

47. Kim DG, Lee DY, Cho BH, You KR, Kim MY, Ahn DS: Down-regulation of insulin-like growth factor binding proteins and growth modulation in hepatoma cells by retinoic acid. Hepatology 1999, 29:1091-1098.

48. White MF: The IRS-1 signaling system. Curr Opin Genet Dev 1994, 4:47-54

49. Caro JF, Poulos J, Ittoop O, Pories WJ, Flickinger EG, Sinha MK: Insulin-like growth factor I binding in hepatocytes from human liver, human hepatoma, and normal, regenerating, and fetal rat liver. J Clin Invest 1988, 81:976-981.

50. Scharf JG, Schmidt-Sandte W, Pahernik SA, Ramadori G, Braulke T, Hartmann $\mathrm{H}$ : Characterization of the insulin-like growth factor axis in a human hepatoma cell line (PLC). Carcinogenesis 1998, 19:2121-2128.

51. Villafuerte BC, Goldstein S, Robertson DG, Pao Cl, Murphy LJ, Phillips LS: Nutrition and somatomedin XXIX. Molecular regulation of IGFBP-1 in hepatocyte primary culture. Diabetes 1992, 41:835-842.

52. So Al, Levitt RJ, Eigl B, Fazli L, Muramaki M, Leung S, Cheang MC, Nielsen TO, Gleave M, Pollak M: Insulin-like growth factor binding protein2 is a novel therapeutic target associated with breast cancer. Clin Cancer Res 2008, 14:6944-6954. 
53. Su TS, Liu WY, Han SH, Jansen M, Yang-Fen TL, P'eng FK, Chou CK: Transcripts of the insulin-like growth factors I and II in human hepatoma. Cancer Res 1989, 49:1773-1777.

54. Schirmacher P, Held WA, Yang D, Chisari FV, Rustum Y, Rogler CE: Reactivation of insulin-like growth factor II during hepatocarcinogenesis in transgenic mice suggests a role in malignant growth. Cancer Res 1992, 52:2549-2556.

55. Casola S, Ungaro P, Pedone PV, Lazzaro D, Fattori E, Ciliberto G, Zarrilli R, Bruni CB, Riccio A: Loss of heterozygosity of imprinted genes in SV 40 t/T antigen-induced hepatocellular carcinomas. Oncogene 1995, 11:711-721.

56. Yang DY, Rogler CE: Analysis of insulin-like growth factor II (IGF-II) expression in neoplastic nodules and hepatocellular carcinomas of woodchucks utilizing in situ hybridization and immunocytochemistry. Carcinogenesis 1991, 12:1893-1901.

57. Harris TM, Rogler LE, Rogler CE: Reactivation of the maternally imprinted IGF2 allele in TGF alpha induced hepatocellular carcinomas in mice. Oncogene 1998, 16:203-209.

58. Cariani E, Lasserre C, Seurin D, Hamelin B, Kemeny F, Franco D, Czech MP, Ullrich A, Brechot C: Differential expression of insulin-like growth factor II mRNA in human primary liver cancers, benign liver tumors and liver cirrhosis. Cancer Res 1988, 48:6844-6849.

59. Sohda T, Oka Y, Iwata K, Gunn J, Kamimura S, Shijo H, Okumura M, Yun K: Co-localisation of insulin-like growth factor II and the proliferation marker MIBI in hepatocellular carcinoma cells. J Clin Pathol 1997, 50:135-137.

60. $\mathrm{Ng} \mathrm{IO}$, Lee JM, Srivastava G, Ng M: Expression of insulin-like growth factor II mRNA in hepatocellular carcinoma. J Gastroenterol Hepatol 1998, 13:152-157.

61. Bae MH, Lee MJ, Bae SK, Lee OH, Lee YM, Park BC, Kim KW: Insulin-like growth factor II (IGF-II) secreted from HepG2 human hepatocellular carcinoma cells shows angiogenic activity. Cancer Lett 1998, 128:41-46.

62. Breuhahn K, Vreden S, Haddad R, Beckebaum S, Stippel D, Flemming P, Nussbaum T, Caselmann WH, Haab BB, Schirmacher P: Molecular profiling of human hepatocellular carcinoma defines mutually exclusive interferon regulation and insulin-like growth factor II overexpression. Cancer Res 2004, 64:6058-6064.

63. Lahm H, Gittner K, Krebs O, Sprague L, Deml E, Oesterle D, Hoeflich A, Wanke $\mathrm{R}$, Wolf E: Diethylnitrosamine induces long-lasting re-expression of insulin-like growth factor II during early stages of liver carcinogenesis in mice. Growth Hormone \& IGF Res 2002, 12:69-79.

64. Mukherjee B, Ghosh S, Das T, Doloi M: Characterization of insulin-likegrowth factor II (IGF II) mRNA positive hepatic altered foci and IGF ॥ expression in hepatocellular carcinoma during diethylnitrosamineinduced hepatocarcinogenesis in rats. J Carcinog 2005, 4:12-25.

65. Rogler CE, Yang D, Rossetti L, Donohoe J, Alt E, Chang CJ, Rosenfeld R, Neely K, Hintz R: Altered body composition and increased frequency of diverse malignancies in insulin-like growth factor-II transgenic mice. J Bio Chem 1994, 269:13779-13784.

66. Uchida K, Kondo M, Takeda S, Osada H, Takahashi T, Nakao A, Takahashi T: Altered transcriptional regulation of the insulin-like growth factor 2 gene in human hepatocellular carcinoma. Mol Carcinog 1997, 18:193-198.

67. Takeda S, Kondo M, Kumada T, Koshikawa T, Ueda R, Nishio M, Osada H, Suzuki H, Nagatake M, Washimi O, Takagi K, Takahashi T, Nakao A, Takahashi T: Allelic-expression imbalance of the insulin-like growth factor 2 gene in hepatocellular carcinoma and underlying disease. Oncogene 1996, 12:1589-1592.

68. Tang SH, Yang DH, Huang W, Zhou M, Zhou HK, Lu XH, Ye G: Differential promoter usage for insulin-like growth factor-II gene in Chinese hepatocellular carcinoma with hepatitis B virus infection. Cancer Detect Prev 2006, 30:192-203.

69. Tsai JF, Jeng JE, Chuang LY, You HL, Ho MS, Lai CS, Wang LY, Hsieh MY, Chen SC, Chuang WL, Lin ZY, Yu ML, Dai CY: Serum insulin-like growth factor-II and a fetal protein as tumor markers of hepatocellular carcinoma. Tumour Biol 2003, 24:291-298.

70. Su Q, Liu YF, Zhang JF, Zhang SX, Li DF, Yang JJ: Expression of insulin-like growth factor II in hepatitis B, cirrhosis and hepatocellular carcinoma: its relationship with hepatitis B virus antigen expression. Hepatology 1994, 20:788-799.

71. Hyashi J, Aoki H, Arakawa Y, Hino O: Hepatitis C virus and heptocarcinogenesis. Intervirology 1999, 42:205-210.
72. Lee YI, Lee S, Lee Y, Bong YS, Hyun SW, Yoo YD, Kim SJ, Kim YW, Poo HR: The human hepatitis $B$ virus transactivator $X$ gene product regulates $\mathrm{Spl}$ mediated transcription of an insulin-like growth factor II promoter 4. Oncogene 1998, 16:2367-2380.

73. Lee Yl, Lee S, Das GC, Park US, Park SM, Lee Yl: Activation of the insulinlike growth factor II transcription by aflatoxin BI induced p53 mutant 249 is caused by activation of transcription complexes; implications for a gain-of-function during the formation of hepatocellular carcinoma. Oncogene 2000, 19:3717-3726.

74. Scharf JG, Ramadori G, Dombrowski F: Analysis of the IGF axis in preneoplastic foci and hepatocellular neoplasms developing after lownumber pancreatic islet transplantation into the livers of streptozotocin diabetic rats. Lab Invest 2000, 80:1399-1411.

75. Dennis PA, Rifkin DB: Cellular activation of latent transforming growth factor beta requires binding to the cation-independent mannose 6-phosphate/insulin-like growth factor type II receptor. Proc Natl Acad Sci USA 1991, 88:580-584.

76. Jirtle RL, Hankins GR, Reisenbichler H, Boyer IJ: Regulation of mannose 6-phosphate/insulin-like growth factor-II receptors and transforming growth factor beta during liver tumor promotion with phenobarbital. Carcinogenesis 1994, 15:1473-1478.

77. Sue SR, Chari RS, Kong FM, Mills JJ, Fine RL, Jirtle RL, Meyers WC: Transforming growth factor-beta receptors and mannose 6-phosphate/ insulin-like growth factor-II receptor expression in human hepatocellular carcinoma. Ann Surg 1995, 222:171-178.

78. Boissan M, Beurel E, Wendum D, Rey C, Lecluse Y, Housset C, Lacombe ML, Desbois-Mouthon C: Overexpression of insulin receptor substrate-2 in human and murine hepatocellular carcinoma. Am J Pathol 2005, 167:869-877.

79. Tanake $S$, Wands $R$ : Insulin receptor substrate 1 overexpression in human hepatocellular carcinoma cells prevents transforming growth factor $\beta 1$ induced apoptosis. Cancer Res 1996, 56:3391-3394.

80. Hundt W, Guccione S, Choi S, Hoffmann R, Bednarski M: Changes of insulin like growth factor binding protein-3 after RF-ablation of a hepatocellular carcinoma [abstract]. Proc Amer Assoc Cancer Res 2004, 45:s5491.

81. Gong Y, Cui L, Minuk GY: The expression of insulin-like growth factor binding proteins in human hepatocellular carcinoma. Mol Cell Biochem 2000, 207:101-104

82. Teishima J: Decreased expression of insulin-like growth factor binding protein-related protein-1 (IGFBP-rP1) in radiation-induced mouse hepatocellular carcinoma. Med J Hiroshima Univ 2002, 50:63-71.

83. Kim HS, Nagalla SR, Oh Y, Wilson E, Roberts CT Jr, Rosenfeld RG: Identification of a family of low affinity insulin-like growth factor binding proteins (IGFBPs): characterization of connective tissue growth factor as a member of the IGFBP superfamily. Proc Natl Acad Sci USA 1997, 94:12981-12986.

84. Pollak MN, Chapman JW, Pritchard KI, Krook JE, Dhaliwal HS, Vandenberg TA, Norris BD, Whelan TJ, Wilson CF, Shepherd LE: NCIC-CTG MA14 trial: Tamoxifen (tam) vs. tam + octreotide (oct) for adjuvant treatment of stage I or II postmenopausal breast cancer [abstract]. J Clin Oncol 2008, 26:5532.

85. Algire C, Zakikhani M, Blouin MJ, Shuai JH, Pollak M: Metformin attenuates the stimulatory effect of a high energy diet on in vivo H59 carcinoma growth. Endocr Relat Cancer 2008, 15:833-839.

86. Goya M, Miyamoto S, Nagai K, Ohki Y, Nakamura K, Shitara K, Maeda H, Sangai T, Kodama K, Endoh Y, Ishii G, Hasebe T, Yonou H, Hatano T, Ogawa Y, Ochiai A: Growth inhibition of human prostate cancer cells in human adult bone implanted into nonobese diabetic/severe combined immunodeficient mice by a ligand-specific antibody to human insulinlike growth factors. Cancer Res 2004, 64:6252-6258.

87. Divisova J, Kuiatse I, Lazard Z, Weiss H, Vreeland F, Hadsell DL, Schiff R, Osborne CK, Lee AV: The growth hormone receptor antagonist pegvisomant blocks both mammary gland development and MCF-7 breast cancer xenograft growth. Breast Cancer Res Treat 2006, 98:315-327.

88. Gao J, Chesebrough JW, Cartlidge SA, Ricketts SA, Incognito L, VeldmanJones M, Blakey DC, Tabrizi M, Jallal B, Trail PA, Coats S, Bosslet K, Chang YS: Dual IGF I/II neutralizing antibody MEDI-573 potently inhibits IGF signaling and tumor growth. Cancer Res 2011, 71:1029-1040.

89. Tovar V, Alsinet C, Villanueva A, Hoshida Y, Chiang DY, Sole M, Thung S, Moyano S, Toffanin S, Minguez B, Cabellos L, Peix J, Schwartz M, Mazzaferro V, Bruix J, Llovet JM: IGF activation in a molecular subclass of 
hepatocellular carcinoma and pre-clinical efficacy of IGF-1R blockage. J Hepatol 2010, 52:550-559.

90. Atzori F, Tabernero J, Cervantes A, Botero M, Hsu K, Brown H, Hanley W, Macarulla T, Rosello S, Baselga J: A phase I, pharmacokinetic and pharmacodynamic study of weekly MK-0646, an insulin-like growth factor-1 receptor monoclonal antibody in patients with advanced solid tumors [abstract]. J Clin Oncol 2008, 26:s3519.

91. Higano CS, Yu EY, Whiting SH, Gordon MS, LoRusso P, Fox F, Katz TL, Roecker JM, Schwartz JD: A phase I, first in man study of weekly IMC-A12, a fully human insulin like growth factor-I receptor lgG1 monoclonal antibody, in patients with advanced solid tumors [abstract]. J Clin Oncol 2007, 25:s3505.

92. Biogen-Idec Inc: Investigator' Brochure of BIIB-022 2010.

93. Karp DD, Paz-Ares LG, Novello S, Haluska P, Garland L, Cardenal F, Blakely $L$, Einsenberg PD, Langer $C$, Blumenschein G Jr, Johnson FM, Green S, Gualberto A: Phase II study of the anti-insulin-like growth factor type I receptor antibody CP-751871 in combination with paclitaxel and carboplatin in previously untreated, locally advanced, or metastatic non small cell lung cancer. J Clin Oncol 2009, 27:2516-2522.

94. Moses AC, Young SC, Morrow LA, O'Brien M, Clemmons DR: Recombinant human insulin-like growth factor I increases insulin sensitivity and improves glycemic control in type II diabetes. Diabetes 1996, 45:91-100.

95. Moller N, Jorgensen JOL, Abildgard N, Orskov L, Schmitz O, Christiansen JS: Effects of growth hormone on glucose metabolism. Horm Res 1991, 36(suppl 1):32-35

96. Gualberto A, Dolled-Filhart M, Gustavson M, Christianen J, Wang YF, Hixon ML, Reynolds J, McDonald S, Ang A, Rimm DL, Langer CJ, Blakely J, Garland L, Paz-Ares LG, Karp DD, Lee AV: Molecular analysis of non-small cell lung cancer identifies subsets with different sensitivity to insulin-like growth factor I receptor inhibition. Clin Cancer Res 2010, 16:4654-4665.

97. Kaseb AO, Morris J, Hassan M, Lin E, Xiao L, Abdalla EK, Vauthey J, Abbruzzese L: Clinical and prognostic implications of plasma IGF-1 and VEGF in patients with hepatocellular carcinoma [abstract]. J Clin Oncol 2011, 29:s155.

98. Abou-Alfa GK, Gansukh B, Chou JF, Shia J, Capanu M, Kalin M, Chen HX, Zojwalla NJ, Katz S, Reidy DL, Kelsen DP, Saltz L: Phase II study of cixutumumab (IMC-A12, NSC742460; C) in hepatocellular carcinoma (HCC) [abstract]. J Clin Oncol 2011, 29:54043.

99. Bladt F, Vrignaud P, Chiron M, Venot C, Dubussche L, Singh R, Chittenden T, Hercend T, Bissery MC: Pre-clinical evaluation of the anti-tumor activity of the IGF1R-specific antibody AVE1642 [abstract]. Proc Amer Assoc Cancer Res 2006, 47:s1225.

100. OSI: Investigator's Brochure of OSI-906 2008

101. Kalli KR, Falowo OI, Bale LK, Zschunke MA, Roche PC, Conover CA: Functional insulin receptors on human epithelial ovarian carcinoma cells: implications for IGF-II mitogenic signaling. Endocrinology 2002, 143:3259-3267.

102. Haluska P, Carboni JM, Loegering DA, Lee FY, Wittman M, Saulnier MG, Frennesson DB, Kalli KR, Conover CA, Attar RM, Kaufmann SH, Gottardis M, Erlichman C: In vitro and in vivo antitumor effects of the dual insulin-like growth factor-1/insulin receptor inhibitor, BMS-554417. Cancer Res 2006, 66:362-371.

103. Ji QS, Mulvihill MJ, Rosenfeld-Franklin M, Cooke A, Feng L, Mak G, O'Connor M, Yao Y, Pirritt C, Buck E, Eyzaguirre A, Arnold LD, Gibson NW, Pachter JA: A novel, potent, and selective insulin-like growth factor-I receptor kinase inhibitor blocks insulin-like growth factor-l receptor signaling in vitro and inhibits insulin-like growth factor-I receptor dependent tumor growth in vivo. Mol Cancer Ther 2007, 6:2158-2167.

104. Zimmermann K, Wittman MD, Saulnier MG, Velaparthi U, Langley DR, Sang X, Frennesson D, Carboni J, Li A, Greer A, Gottardis M, Attar RM, Yang Z, Balimane P, Discenza LN, Vyas D: Balancing oral exposure with Cyp3A4 inhibition in benzimidazole-based IGF-IR inhibitors. Bioorg Med Chem Lett 2008, 18:4075-4080.

105. Mulvihill MJ, Ji QS, Coate HR, Cooke A, Dong H, Feng L, Foreman K, Rosenfeld-Franklin M, Honda A, Mak G, Mulvihill KM, Nigro Al, O'Connor M, Pirrit C, Steinig AG, Siu K, Stolz KM, Sun Y, Tavares PA, Yao Y, Gibson NW: Novel 2-phenylquinolin-7-yl-derived imidazo[1,5-a]pyrazines as potent insulin-like growth factor-I receptor (IGF-IR) inhibitors. Bioorg Med Chem 2008, 16:1359-1375.
106. Hofmann F, Garcia-Echeverria C: Blocking the insulin-like growth factor-I receptor as a strategy for targeting cancer. Drug Discov Today 2005, 10:1041-1047.

107. Vasilcanu R, Vasilcanu D, Rosengren L, Natalishvili N, Sehat B, Yin S, Girnita A, Axelson M, Girnita L, Larsson O: Picropodophyllin induces downregulation of the insulin-like growth factor 1 receptor: potential mechanistic involvement of Mdm2 and beta-arrestin1. Oncogene 2008, 27:1629-1638.

108. Barlaskar FM, Hammer GD: The molecular genetics of adrenocortical carcinoma. Rev Endocr Metab Disord 2007, 8:343-348.

109. Wang Z, Ruan YB, Guan Y, Liu SH: Expression of IGF-II in early experimental hepatocellular carcinomas and its significance in early diagnosis. World I Gastroenterol 2003, 9:267-270.

110. Phoenix KN, Vumbaca F, Claffey KP: Therapeutic metformin/AMPK activation promotes the angiogenic phenotype in the ER alpha negative MDA-MB-435 breast cancer model. Breast Cancer Res Treat 2009, 113:101-111.

111. Liang J, Shan H, Shao SH, Xu ZX, Hennessy B, Ding Z, Larrea M, Kondo S, Dumont DJ, Gutterman JU, Walker CL, Slingerland JM, Mills JB: The energy sensing LKB1-AMPK pathway regulates $\mathrm{p} 27^{\mathrm{kip} 1}$ phosphorylation mediating the decision to enter autophagy or apoptosis. Nature Cell Biol 2007, 9:218-224.

112. Borger DR, Gavrilescu LC, Bucur MC, Ivan M, Decaprio JA: AMP-activated protein kinase is essential for survival in chronic hypoxia. Biochem Biophys Res Commun 2008, 370:230-234

113. Winski SL, Anderson D, Litwiler KS, Munson M, Lee PA, Winkler JD: Effects of ARRY-797, a potent small molecule p38 MAPK inhibitor, on in vivo xenograft tumor growth, alone and in combination with cytotoxic agents [abstract]. Ann Oncol 2007, 18:s202.

114. Jones HE, Goddard L, Gee JMW, Hiscox S, Rubini M, Barrow D, Knowlden JM, Williams S, Wakeling AE, Nicholson RI: Insulin-like growth factor-I receptor signaling and acquired resistance to gefitinib (ZD 1839; Iressa) in human breast and prostate cancer cells. Endocr Relat Cancer 2004, 11:793-814.

115. Wan X, Harkavy B, Shen N, Grohar P, Helman L: Rapamycin induces feedback activation of Akt signaling through an IGF-1R-dependent mechanism. Oncogene 2007, 26:1932-1940.

116. O'Reilly KE, Rojo F, She QB, Solit D, Mills GB, Smith D, Lane H, Hofmann F, Hicklin DJ, Ludwig DL, Baselga J, Rosen N: mTOR inhibition induces upstream receptor tyrosine kinase signaling and activates Akt. Cancer Res 2006, 66:1500-1508.

117. World Health Organization: Global action against cancer. World Health Organization Press. Geneva; 2005.

118. Kurzrock R, Patnaik A, Aisner J, Warren T, Leong S, Benjamin R, Eckhardt SG, Eid JE, Greig G, Habben K, McCarthy CD, Gore L: A phase I study of weekly R1507, a human monoclonal antibody insulin-like growth factor-I receptor antagonist, in patients with advanced solid tumors. Clin Cancer Res 2010, 16:2458-2465.

119. Tolcher AW, Sarantopoulos J, Patnaik A, Papadopoulos K, Lin CC, Rodon J, Murphy B, Roth B, McCaffery I, Gorski KS, Kaiser B, Zhu M, Deng H, Friberg G, Puzanov I: Phase I, pharmacokinetic and pharmacodynamic study of AMG479, a fully human monoclonal antibody to insulin-like growth factor receptor 1. J Clin Oncol 2009, 27:5800-5807.

120. Garcia-Echeverria C, Pearson MA, Marti A, Meyer T, Meston J, Zimmermann J, Gao J, Brueggen JF, Capraro HG, Cozens R, Evan DB, Fabbro D, Furet P, Porta DG, Liebetanz J, Martiny-Baron G, Ruetz S, Hofmann F: In vivo antitumor activity of NVP-AEW541- A novel, potent, and selective inhibitor of IGF-IR kinase. Cancer Cell 2004, 5:231-239.

121. Zhou H, Rao J, Lin J, Yin B, Sheng H, Lin F, Zhang N, Yang L: The insulinlike growth factor -I receptor inhibitor NVP-ADW 742 sensitizes medulloblastoma to the effects of chemotherapy. Oncol Rep 2010, 25:1565-1571.

\section{doi:10.1186/1756-8722-4-30}

Cite this article as: Wu and Zhu: Targeting insulin-like growth factor axis in hepatocellular carcinoma. Journal of Hematology \& Oncology 2011 4:30. 